\title{
EFFECT OF REPLACING FINE AGGREGATE WITH BOTTOM ASH IN M40 GRADE OF CONCRETE WITH OPC-53S CEMENT
}

\author{
P.Ranapratap ${ }^{1}$, K.Padmanabham ${ }^{2}$ \\ ${ }^{I}$ M.Tech Student, Department of Civil Engineering, GVP College of engineering, Andhra Pradesh, India \\ ${ }^{2}$ Associate Professor, Department of Civil Engineering, GVP College of Engineering, Andhra Pradesh, India
}

\begin{abstract}
There is an emergency need to promote sustainable cement concrete and its development by using alternative materials, to reduce the emission of green-house gases and for the disposal of vast bottom ash product from the power plants. In India there is a growing concern about scarcity of river sand which is a prime source of material used in the manufacture of cement concrete. In this context, this paper presentation establish the experimental results about strength and economic aspects of concrete, by partial sand replacement with bottom ash in the concrete. Also experimental results presented about the partial replacement of crusher dust and robo sand with bottom ash, as these products are treated as an alternative measures of natural sand. The aim of this project work is to efficient utilization of Industrial wastes for high strength and durable concrete mix. Experimental studies are conducted on M40 grade concrete prepared with 53 Grade special cement and replacement fine aggregate with bottom ash. The investigation on compressive strength of the concrete at different ages such as 7 days, 14 days and 28 days are observed when the bottom ash is replaced 0\%, 10\%, 20\%, 30\%, 40\%, 50\%, and 60\% in the place of three control mixes of sand, robo sand and crusher dust which are treated as fine aggregate. The results showed that the optimum dosage of bottom ash when it is replaced with sand/ robo sand /crusher dust is $10 \%$ at 28days compressive strength of concrete. OPC 53 Grade special cement is selected for the purpose of attaining high early strength of concrete. The bottom ash is obtained from National Thermal Power Plants (NTPC) Parawada in Visakhapatnam District of Andhra Pradesh State. It has wide potential to utilize as a raw material for concrete brick industry, and for Ready mix concrete.
\end{abstract}

Keywords: Bottom Ash, Crusher Dust, Robo Sand, Controlled Concrete.

\section{INTRODUCTION}

Concrete, the second mostly used engineering material in the world after water and addition of some other materials may change the concrete properties. It is the composite material most used for the construction of high rise buildings and various Infrastructure developments area particularly in the developing countries like India is more. Concrete is a form of mixing cement, fine and coarse aggregate in addition to water. In general, the fine aggregate used in the production of concrete was Natural River sand. Now a days, these natural sources like river sand are exhausting gradually around the world. So, the protection of environment and saving of natural resources the construction industry is look for the alternative constituent material for making concrete. So, there is a need for Replacement of sand. In India, major portion of electricity generated by burning of coal resulting as formed as ash. The ashcontents comes from the burning of coal has to be disposed as either in dry state or in wet state to available open areas nearer the plant or both the fly ash and bottom ash grounding and mixing with water and send into lagoons. These are open to atmosphere causes environmental pollution and loss of productive land. Bottom ash is obtaining from bottom of the furnace with burning coal at thermal power plants. The use of bottom ash in high strength concrete is a new dimension in concrete mix design. The chemical composition of bottom ash is similar to fly ash but it contains more carbon quantity than fly ash. BA is a coarser angular material having porous surface texture and distributed the particle size nearly equal to the sand.It exhibits the engineering properties like high shear strength and low compressibility that makes as used in construction applications. It has not only a constructability benefits and also proved to be an economical. So, Government should encouraging the bottom ashusage and its related products as a large amount of quantities for many civil engineering construction purpose.

\section{LITERATURE REVIEW}

P.Agarwal. Y.Agarwal And S.M.Gupta were studied the effect of bottom ash as replacement of fine aggregate in concrete they concluded thatthe compressive, flexural and split tensile strengths of fine aggregate replaced with bottom ash concrete, the strengths were lower than the controlled concrete at all ages of curing. The workability of concrete decreases with increase in percentage of bottom ash content, this can be avoid by using superplasticizer.

M. P. Kadam and Dr. Y. D. Patil were studied the effect of coal bottom ash as sand replacement on the properties of concrete with different $\mathrm{w} / \mathrm{c}$ ratio. They concluded that $30 \%$ bottom ashreplacement is optimum. Up to $30 \%$ replacement of fine aggregate with bottom ash the compressive, flexural and split tensile strengths are increased for all 7, 10 14, 28, 56 and 90 days of curing. 
Dilip Kumar, Ashish Gupta and Sri Ramwere studied the use of bottom ash as replacement of fine aggregate for making concrete. They concluded that after $40 \%$ replacement of bottom ash in the concrete, the compressive and flexural strengths are decreasing.

\section{MATERIALS USED}

The following materials were used for preparing the test specimens

- Ordinary Portland special cement (OPC-53s)

- Aggregates (20mm \& 10mm down)

- $\quad$ Sand (zone III-Natural River Sand)

- $\quad$ Bottom ash (zone IV- NTPC Vizag)

- $\quad$ Robo Sand (zone II-Anakapalii)

- Crusher Dust (zone III-Vepagunta)

- Portable water

\section{DESIGN PROCEDURE}

The IS 10262-2009 Recommended Practice for Selecting Proportions for Concrete.

M40 Mix Design Procedure:

Design Stipulations

Grade of concrete: M40

Size of aggregate: $20 \mathrm{~mm} \& 10 \mathrm{~mm}$

Degree of quality control: good

Type of exposure: severe

Grade of Cement: 53 grade ordinary Portland special cement

\section{Test Data for Materials}

Specific gravity of Cement: 3.15

Specific gravity of fine aggregate: 2.52

Specific gravity of coarse aggregate: 2.73

Aggregate Impact value: 24\% (Exceptionally Strong)

Fineness modulus of fine aggregate: 2.2

Fineness modulus of coarse aggregate: 6.6

Fine aggregate: Sand zone III according to IS:383- 1970

\section{Target Mean Strength:}

Fck' $=$ Target Mean Strength

Fck $=$ Specified Characteristic Compressive Strength of concrete $=40 \mathrm{~N} / \mathrm{mm}^{2}$

$\mathrm{S}=$ Standard deviation $=5$

Target Mean Strength, Fck' $=$ Fck $+1.65 * \mathrm{~S}$

$=40+1.65 * 5=48.24 \mathrm{~N} / \mathrm{mm}^{2}$

Step-1 Choice of slump

Height of Slump is considered as $100 \mathrm{~mm}$.

Step-2 Choice of maximum size of aggregate

The maximum size of Coarse aggregate is considered as 20 $\mathrm{mm}$

Step-3 Estimation of mixing water quantity

From table - 2 of IS 10262-2009, maximum water content for $20 \mathrm{~mm}$ aggregate $=186$ liters (for 25 to $50 \mathrm{~mm}$ slump)

Estimated water content for $100 \mathrm{~mm}$ slump $=197$ liters.

Step-4 Selection of water/Cement ratio 0.45

Step-5 Calculation of Cement content

Water/Cement ratio $=0.45$

Water content $\quad=197 \mathrm{Kg} / \mathrm{m} 3$

Cement content $=197 / 0.45=437.77 \mathrm{~kg}$
Step-6 Estimation of coarse and fine aggregate content Form table-3 of IS 10262-2009. Volume of fine aggregate by considering coarse aggregate size $20 \mathrm{~mm}$ and water cement ratio

The volume of coarse aggregate $=0.64$

Considering the corrections the volume of the coarse aggregate is $=0.65$.

Volume of fine aggregate $=0.35$.

Step-7 Volume based calculations

Volume of concrete $=1 \mathrm{~m}^{3}$

Volume of Cement $=0.138 \mathrm{~m}^{3}$

Volume of water $=0.197 \mathrm{~m}^{3}$

Volume of all in aggregate $=0.675 \mathrm{~m}^{3}$

Mass of coarse aggregate $=1174 \mathrm{~kg}$.

Mass of fine aggregate $=584 \mathrm{~kg}$

Mix proportions for 1 meter cube:

Cement $=437 \mathrm{~kg} / \mathrm{m}^{3}$

Fine aggregate $=584 \mathrm{~kg} / \mathrm{m}^{3}$

Coarse aggregate $=1174 \mathrm{~kg} / \mathrm{m}^{3}$

Water $=197 \mathrm{lt} / \mathrm{m}^{3}$

Final Mix Proportions-

C : F.A : C.A

$1: 1.3: 2.7$

Table-1: Mix Proportions for $1 \mathrm{~m}^{3}$ Concrete

\begin{tabular}{|c|c|c|c|c|}
\hline $\begin{array}{l}\text { Mix } \\
\text { Designa } \\
\text { tion }\end{array}$ & $\begin{array}{l}\text { Cement } \\
\mathrm{Kg} / \mathrm{m}^{3}\end{array}$ & $\begin{array}{l}\text { Bottom } \\
\text { Ash } \\
\text { Kg/m }\end{array}$ & $\begin{array}{l}\text { Fine } \\
\text { Aggregat } \\
\text { eKg/m } 3\end{array}$ & $\begin{array}{l}\text { Coarse } \\
\text { Aggregat } \\
\text { eKg/m }\end{array}$ \\
\hline BA0 & 410 & 0 & 584 & 1174 \\
\hline BA10 & 410 & 58.4 & 525.6 & 1174 \\
\hline BA20 & 410 & 116.8 & 467.2 & 1174 \\
\hline BA30 & 410 & 175.2 & 408.8 & 1174 \\
\hline BA40 & 410 & 233.6 & 350.4 & 1174 \\
\hline BA50 & 410 & 292 & 292 & 1174 \\
\hline ВА60 & 410 & 350.4 & 233.6 & 1174 \\
\hline
\end{tabular}

Note: BA0 means bottom ash $0 \%$ and fine aggregate $100 \%$

\section{EXPERIMENTAL TEST RESULTS}

All cubes are casted $150 \mathrm{~cm} \mathrm{X} 150 \mathrm{~cm} \mathrm{X} 150 \mathrm{~cm}$. Concrete used in this study were M40 grade and binder used was Nagarjuna cement OPC-53s. Sand, robo sand and crusher dust are used as fine aggregate and course aggregate was locally available granite stone sieved to $10 \mathrm{~mm}$ and $20 \mathrm{~mm}$ of $40 \%$ and $60 \%$ respectively. The concrete mix proportions for the cement, fine and coarse aggregate were $1: 1.3: 2.7$ respectively and $\mathrm{W} / \mathrm{C}$ ratio was 0.45 by weight. The specimens are cured and tested at 7 days, 14 days and 28 days.

Table-2: Compressive Strength of Concrete with OPC 53-S Cement (Sand Replaced with Bottom Ash)

\begin{tabular}{|l|l|l|l|}
\hline \multirow{2}{*}{$\begin{array}{l}\text { Mix } \\
\text { Designation }\end{array}$} & \multicolumn{3}{|l|}{ Average Compressive Strength N/mm ${ }^{2}$} \\
\cline { 2 - 4 } & 7 Days & 14 Days & 28 Days \\
\hline BA0 & 35.16 & 43.1 & 46.5 \\
\hline BA10 & 35.66 & 43.83 & 46.8 \\
\hline BA20 & 32.83 & 40.16 & 44.83 \\
\hline BA30 & 30.5 & 38.1 & 42.1 \\
\hline BA40 & 28.83 & 34.16 & 39.3 \\
\hline BA50 & 25.5 & 29.83 & 35.66 \\
\hline BA60 & 21.5 & 27.66 & 33.16 \\
\hline
\end{tabular}


Table-3: Compressive Strength of Concrete with OPC 53-S Cement (Robo Sand Replaced with Bottom Ash)

\begin{tabular}{|l|l|l|l|}
\hline \multirow{2}{*}{$\begin{array}{l}\text { Mix } \\
\text { Designation }\end{array}$} & \multicolumn{3}{|l|}{ Average Compressive Strength N/mm ${ }^{2}$} \\
\cline { 2 - 4 } & 7 Days & 14 Days & 28 Days \\
\hline BA0 & 34.83 & 40.1 & 43.1 \\
\hline BA10 & 35.1 & 42.16 & 44 \\
\hline BA20 & 31.5 & 38 & 41.5 \\
\hline BA30 & 28.66 & 35.1 & 39.1 \\
\hline BA40 & 25.0 & 29.3 & 36.16 \\
\hline BA50 & 20.83 & 24.5 & 33.5 \\
\hline BA60 & 17.66 & 22.66 & 30.83 \\
\hline
\end{tabular}

Table-4: Compressive Strength of Concrete with OPC 53-S Cement (Crusher Dust Sand Replaced with Bottom Ash)

\begin{tabular}{|l|l|l|l|}
\hline \multirow{2}{*}{$\begin{array}{l}\text { Mix } \\
\text { Designation }\end{array}$} & \multicolumn{3}{|l|}{ Average Compressive Strength N/mm ${ }^{2}$} \\
\cline { 2 - 4 } & 7 Days & 14 Days & 28 Days \\
\hline BA0 & 36 & 43.5 & 48.8 \\
\hline BA10 & 36.5 & 44.5 & 49.1 \\
\hline BA20 & 33.1 & 42.1 & 46 \\
\hline BA30 & 31.66 & 38.5 & 42.83 \\
\hline BA40 & 29.5 & 34.14 & 40.16 \\
\hline BA50 & 26.5 & 32.83 & 37.5 \\
\hline BA60 & 23.1 & 29.83 & 35.16 \\
\hline
\end{tabular}

Note: BA10 means bottom ash $10 \%$ and fine aggregate $90 \%$

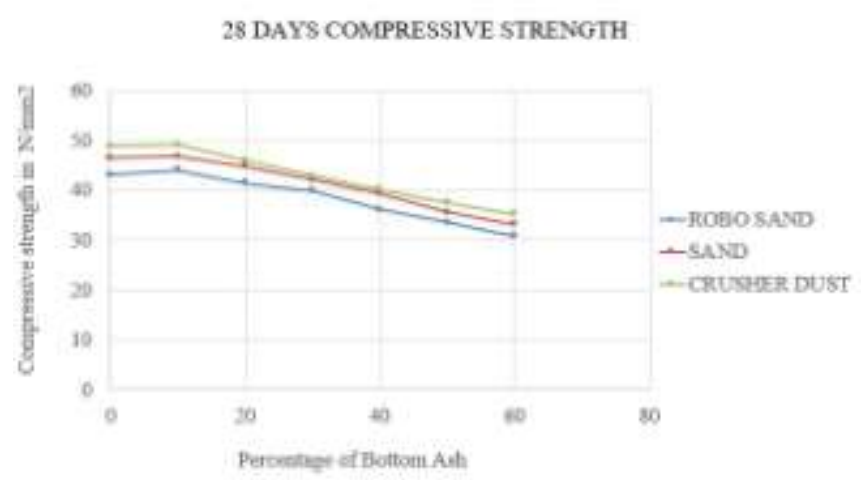

Graph-1: Showing Replacement of Fine Aggregates with Bottom ash

\section{WORKABILITY}

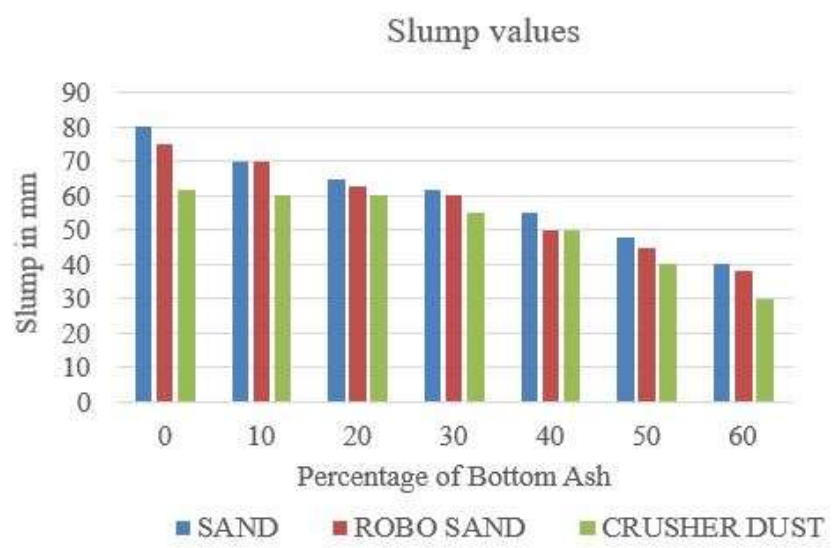

Note: Workability decreases with increasing percentage replacement of bottom ash in concrete mix

\section{COST COMPARISON OF CONCRETE MIXES}

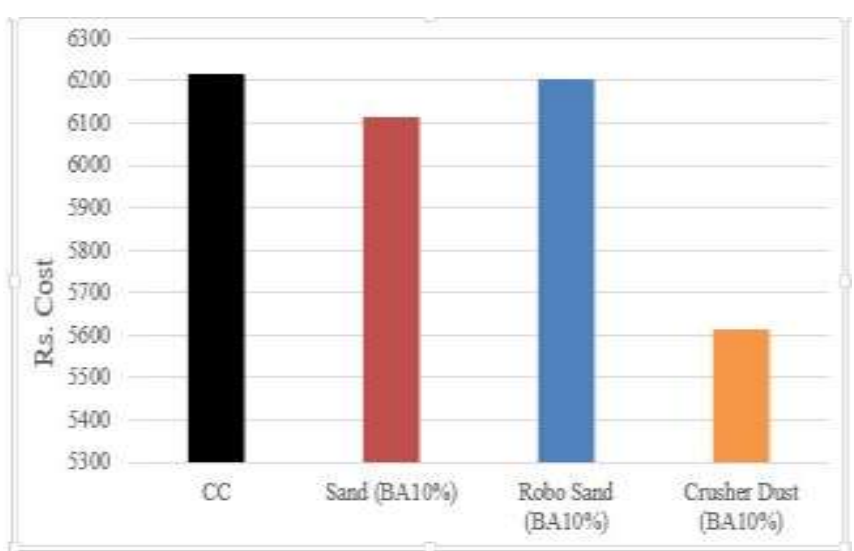

NOTE:CC: Control concrete mix (100\% sand)

Sand (BA10\%): 90\% sand $+10 \%$ Bottom Ash

Robo Sand (BA10\%): 90\% Robo sand + 10\% Bottom Ash Crusher Dust (BA 10\%): $90 \%$ Crusher dust $+10 \%$ Bottom Ash.

\section{CONCLUSION}

1. Based on the experimental test results the optimum dosage of bottom ash found $10 \%$ [by weight] for M40 grade concrete.

2. The optimum dosage of bottom ash is remains same for river sand, robo sand and crusher dust which are used for the replacement of fine aggregate in the concrete.

3. The compressive strength of concrete is not affected when the fine aggregate is replaced by the bottom ash at optimum dosage $(10 \%)$.

4. From the observations of the project, it was justified that each bag of cement consumption in concrete reduced $4 \mathrm{Kg}$ weight of bottom ash when it used as a replacement material of fine aggregate.

5. Workability of concrete not seriously affected at optimum dose of bottom ash. The slump test results exhibited reduced workability by $12 \%$ in comparison with controlled concrete.

6. From economic point of view there are a notable observations when we use bottom ash replacement to fine aggregate.

i. If $10 \%$ quantity of sand in controlled concrete is replaced with the bottom ash, then the cost reduced by $1.7 \%$.

ii. If $10 \% \%$ quantity of robo-sand in controlled concrete is replaced with the bottom ash then there is no change in cost. iii. If $10 \%$ quantity of crusher dust in concrete is replaced by the bottom ash, then the cost is reduced by $9.7 \%$.

7. For developing sustainable concrete, bottom ash proves to be a good alternative. The $10 \%$ optimum dosage of bottom ash replacement saves a large consumption of river sand which is used in concrete. 
8. For the environmental point of view, the proportional replacement of aggregate with bottom ash not only reduce the cost of concrete but also encourage huge disposal of ash contents which is daily generated from thermal power plants.

\section{REFERENCES}

[1]. Dilip Kumar, Ashish Gupta and Sri Ram (2014) "Use of Bottom Ash as Replacement of Fine Aggregate for Making Concrete", IJCET, Vol 4, No 6, pp 3891-3895

[2]. Remya Raju, Mathews M. Paul and K. A. Aboobacker (2014), "Strength Performance of Concrete using Bottom Ash as Fine Aggregate", International Journal of Research in Engineering \& Technology (IJRET), ISSN (e): 23218843, ISSN (p): 2347-4599, Volume 2, Issue 9, September 2014, pp.111-122.

[3]. K. Soman, DivyaSasi and K.A. Abubaker (2014), "Strength properties of concrete with partial replacement of sand by bottom ash", International Journal of Innovative Research in Advanced Engineering (IJIRAE), ISSN: 23492163, Volume 1, Issue 7, August 2014, pp.223-227

[4]. Agarwal P, Agarwal Y, Gupta S.M (2007), "Effect of Bottom Ash as Replacement of Fine Aggregates in concrete ", Asian Journal of Civil Engineering (BUILDING AND HOUSING ) Vol 8,No 1,pp 49-62.

[5]. M. S. Shetty (2013), Concrete Technology, S. Chand \&co publishing company.

[6]. IS 383-1970. Specifications for coarse and fine aggregate from natural sources for concrete, Bureau of Indian Standards, New Delhi, India.

[7]. IS 12269-2013.Specifications of OPC 53-S Cement, Bureau of Indian Standards, New Delhi, India

[8]. IS 10262-2009.Recommendation guidelines for concrete mix design,Bureau of Indian Standards, New Delhi, India [9]. IS 516-1959.Indian standard code of practice Methods of test for strength of concrete, Bureau of Indian Standards, New Delhi, India

\section{BIOGRAPHIE}

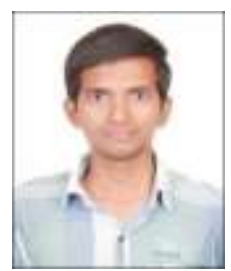

P. Ranapratap, P.G Student, GVP College of Engineering, Visakhapatnam, A.P., P No: 9441744257

Email: ranap6698@gmail.com 